\title{
Boundry and Customary Land Ownership Dispute in Sarawak
}

\author{
Azima A.M. ${ }^{1}$ \\ Sivapalan, S. ${ }^{2}$ \\ Zaimah $\mathbf{R}^{3}$ \\ Suhana S. ${ }^{4}$ \\ Mohd Yusof $\mathrm{H}^{5}$ \\ ${ }^{1}$ Associate Professor, Faculty of Social Siences and Humanities, Universiti Kebangsaan Malaysia \\ azima@ukm.edu.my \\ ${ }^{2}$ Associate Professor, Faculty of Social Siences and Humanities, Universiti Kebangsaan Malaysia \\ sivap_02@gmail.com \\ ${ }^{3}$ Senior Lecturer, Faculty of Social Siences and Humanities, Universiti Kebangsaan Malaysia \\ zaimahr@ukm.edu.my \\ ${ }^{4}$ Associate Professor, Faculty of Social Siences and Humanities, Universiti Kebangsaan Malaysi \\ suhanasaad@ukm.edu.my \\ ${ }^{5}$ Associate Professor, Faculty of Social Siences and Humanities, Universiti Kebangsaan Malaysia \\ hmyusoff@ukm.edu.my
}

\section{Doi:10.5901/mjss.2015.v6n4s3p17}

\section{Abstract}

Customary land ownership dispute have been clearly attributed to three main factors, namely status, ownership validity and the actual area of land owned. Society's conflict in relation to the matter can be attributed to the way the information is obtained. Most of the customary land owners obtained their land information orally; through word of mouth information. This matter has finally become a major challenge to the community when it comes to various assumptions and different interpretations related to the status and validity of the customary land owned. Hence, this study aims to reveal the feedback from the customary landowners in relation to the determination of the boundaries of the land among the Bidayuh community in Serian District, Sarawak. Besides that, the study also drew attention to the delimitation of the customary land disputes and its implications among the customary landowners. Information related to the purpose of the study was gathered through the focus group discussions and in-depth interviews with the customary landowners in the study area. The study found that there are several ways of defining the boundaries among the landowners. Accordingly, it can be concluded that land disputes in the study area are driven by issues of status and validity of ownership of land owned by customary land owners. To reduce the conflict, it was suggested that the available land are be measured by a qualified surveyor. Thus, when the land was measured, the landowner will obtain a clearer land title in terms of status and ownership of validity.

Keywords: customary land, border, delimitation, dispute and ownership

\section{Introduction}

In short, customary land is defined as the right of ownership of the land acquired through hereditary from generation to generation (Verplank McCall 2014). The right to use the customary land is managed by the community through the power implicitly understood only by them (Paaga 2013). The power to transfer and acquisition are non-formally recorded in the community through oral information. According to Cotula (2006), custom is the only legitimate guideline that exists in the tradition of a society.This tradition refers to a set of norms, values and practices among the locals or community groups. While Fleischacker (1994), defines tradition as a set of custom handed down from one generation to another involving values and beliefs that have been adopted within a society. Refering to the Bidayuh community in Sarawak, traditionally they bequeath the rights to use the land by practicing their customs from generation to generation.The Bidayuh's community method of customary land ownership is through inheritance, handed down from one generation to another and recognized as valid by the customary leader or the tuai rumah (Azima et al 2014). Among the native community, the customary land owners are more of a trustee and the land in entity exists to safeguard the interests and the continuance 
of the community (Azima 2014; Kirby 2005). This is in consistent with the view of Wehrmann (2003), which explains that the customary land is a commodity that is norm and value in nature to the owner. This means that not only customary land be extremely valuable in the communities' economy and politic but be very valuable in their spiritual and ritual context. Thus, it is not surprising that the customary land be seen as a continuation of the identity of the native people. To the extent that, some of them believe without the land the native and tribal identity cannot be continued.

This situation explains the need of the native people to the land ownership in the context of a valid and clear ownership. This matter has been realized by them since their early settlements when the land began to be explored. Therefore, validity or the proof of land ownership has been marked by the land boundry visualized through information understood and shared with the community members. This is due to the line boundaries of the land that can be defined as the law, able to limit the ownership of an individual to a piece of land. Hallman (1994) explains that the boundary line is also known as the line of ownership of which can be defined as a legal boundary of a piece of land. In terms of law, it is a sign or monument used and recognized in the context of defining the boundaries. This matter is evident when Keres et. al (2014) found that traditionlly, the customary land boundaries are marked using a stack of pebbles or stones, or other appropriate material. As examples, studies on the customary land boundries in Fiji by Keres et al (2014); Rakai et al (1995), Stephan at al 2007 and Verplank and Mc Call (2014), Azima et al. (2014) also found that the customary land boundaries are traditionally marked by stones, mountains, ridges, rivers, trees and so on. However, marking in the form of this natural material is susceptible to destruction by the natural reason and unreliable for the purpose of marking. This is due to the demarcation visualization of the boundry by most of these customary land does not reflect holdings of individuals, does not have a high market value and not surveyed for clearer mapping purposes. Eventually, this matter has created many disputes that relate to the boundries and further create the overlapping ownership, disputes between owners and land ownership dispute with the administration (Verplank and Mc Call 2014). Therefore, it is important for this study to understand the visualization of the locals in relation to the land boundry.

\section{Literature Review on the concept of Customary Land In Sarawak}

According to Kasanga \& Kotey (2001), the colonial had allowed the customary land to be continued in their system of government administration. This matter is important to enable the colonial to win the trust and support of the community. For example, in Sarawak, in 1939, the Brooke Government had issued Circular No 12 (Secretariat Circular No 12) to formally record the customary land boundaries. The purpose of marking and recording the boundries is for the community to trail and demarcate their menoa boundaries. It is also aimed at preventing the encroachment and strife between communities. As for the government, the customary land boundaries are to prevent the native people from exploring the government land without prior approval of the District Officer (DO). The British have recorded the Bumiputra land boundaries (NCL) by making a sketch map of the land area. These records are kept at the District Office collected in a book called the Boundary Book. Evidences of the NCR land encompasses of the physical signs marking the boundaries of the original formation of the menoa boundries, community custom, Circular No 12 / 1939 official records (Borders Book) (BRIMAS 1999).

According to the Sarawak Land Code 1957, the Bumiputra customary land (NCL) is recognized (BRIMAS 1999). This matter is obvious when there are a few laws protectingt the customary land rights as the provisions in Chapter 21 of the Sarawak Land Code Section 2 (a), Section 5 (2) and Section 15 (1), which emphasized on the definition, method of ownership and the protection of customary land rights. Generally, the native people have no written records of their menoa land boundaries. Their knowledge on the boundaries of the land were orally obtained through verbal signs such as hills, mountains, clumps of bamboo, wood, rivers and so on. Defining the boundaries between menoa were done by the agreement between the affected individuals and the community according to their customs. Encroachment in context of the breach of understanding between the individuals or communities will be resolved by the judgment made by the customary leader or tuai rumah and if it is not resolved, the case will then be referred to the Court of Headman. This matter explains that the customary land has its legitimacy because the Native Court recognizes the customary land ownership by the owner. In this matter, the case will be tried whereby the prosecuting party and the party being prosecuted must submit the evidence to prove claims against the land.

Dispute relating to the land occurs when there are different interpretations of the customary land definitions in the community. Confusion of different interpretations arised when there were those involved in the development that do not have the knowledge and clear understanding of the status, existence, validity and the actual land area that allows the land to be declared as a customary land. Disputes relating to the NCR land boundaries become complicated when there were among the land owners who made their own interpretation in classifying the NCR land. This matter became more complicated when there is state-owned land that was claimed as the NCR land. It will certainly create a dispute about the 
status of the land. Therefore, an explanation to classify whether a piece of the NCR land is belong to the community, can be classified based on the land code that has been used before January 1, 1958. The meaning used here is that the land was cleared for agricultural activities, settlements or cemeteries (Borneo Post, 2012). After January 1, 1958, the native communities are no longer allowed to occupy or open a new area of land other than that found in their menoa area. In this regard, the Land and Survey Department has targeted 1.5 million hectares of NCR land to be surveyed by 2015. Currently 2,000 hectares have been surveyed and gazetted. The measurement is to state the valid boundaries between the NCR land and the state land so that there will be no wrong claims in the future (Borneo Post 2012). Upon completion of this stage, the government will measure the boundaries of the land owned by individuals within the gazetted NCR measured before. It was followed by granting the land title deeds to the NCR land owners.

Therefore, it is important for the native people to record the history of the community and gather and make copies of documents concerning the existence of the menoa boundries. All the information are important in order to avoid ownership disputes between communities or individuals, in addition, it can be used as the evidence to negotiate with the parties involved in the event of land acquisition for development purposes. It can also be used as an evident if there is any court action. As customary land ownership is related to the customs of a community, it is important to make notes on places that are associated with the ritual such as the graves are also recorded. At the same time, the younger generation should be taught about the traditional practice. It is clear from the experience in several areas in Africa, particularly in the sub-Saharan Africa who have intergrated the traditional and modern practices in the context of ownership (Verplank and Mc Call 2014). In this case, some informal rights to the land have been designed together in a planned development policy.

\section{Research Methods}

The study design is descriptive in nature. This matter is in accordance with the study issue that emphasizes on the sociocultural and the customary land owner power to the boundary and the land dispute among the Bidayuh in Serian, Sarawak. The descriptive approach is suitable as the main focus involve the social experience of the land owners in determining the boundaries of their land and its relation to the disputes over ownership rights to the land in the study area. The population of this study emphasizes on the customary landowners in some selected villages in the district of Serian, Sarawak, which is famous for its oral boundry determination among the community. The villages involved included Kg Kekai, Kg Pridang, Kg Diang, Kg Mentu Tapu, Kg Tong Nibong and Kg Mongkos. Accordingly, the focus group interviews and the in-depth interviews with the customary land owners in the study area were conducted. Which is included 70 land owners of customary land in the six villages. The goal is to obtain their method of defining the boundaries and the dispute on their rights to the land.

\section{Results of the Study and Discussions}

\subsection{Determination Of The Boundary And Ownership Dispute}

The demarcation of the land boundary to determine the ownership in the study area is heavily influenced by the historical factor. Through the settlement history of the community, it has been recognized by the local leaders as the valid ownership. This recognition is the proof of status and the validity of their ownership. Majority of the land owners met admitted that the status of the land they own is the native customary land (NCR) and the interviews clearly showed their confidence in terms of ownership validity of the land owned by them. The analysis has found some components that explained the existence proof of land ownership as an effect from the delimitation jointly agreed upon by the community in the study area. Among others which include the determination of land boundaries through history and the determination of the boundaries through physical signs.

\subsection{Determination of boundaries through history}

Generally, majority of the Bidayuh community inherited the NCR land before the Japanese War. The inheritance method was from one generation to another certified by the head of customs that is the tuai rumah (Azima et al 2014). Narration by the landowners in relation to the validity of the ownership is related to the early history of their settlement in the study area. Most of the landowners met stated that the land they occupied had been occupied by their ancestors since the Japan time. In fact, there were among the landowners who could provide the year of their arrivals in the area. For example, landowner $X$ from kampung Mongkos narrated that; 
"...It's around 1911, people live here ... I was born in 1935, it was our ancestors. It is from there we know the land... cut down, throw away ... this land was not cleared by the Mongkos. It was cleared by the Mentu. Kampung Mentu is there. So Mena was asked to fight, if the Mentu managed to defeat the chief, land will be given to them. Give the property. So fight with the Jegu chief, the Jegu chief was defeated and died. People want to give food. We give the Menak. But his name was changed to Sugit. The chief has two names. So, fight with the Jegu chief, the Jegu chief died, the Mentu give property as a reward. I don't want. They want to reward me with land as a prize or honour.. The Mentu gave the land first, Ulu Mongkos, Ulu Peruntang and Ulu Tiram, Ulu Bertam, he gave all to Menak. He made between there and here. So we live here are the Menak's grandchild. That is why this land is a lot bigger belongs to Mongkos because it is the reward from the Menak's chief fights, given to the grandchild. The one that belongs to us that was divided..."

This explained that the history of the ancestors' heroism had enabled them to own the land which was previously owned by the Mongkos tribe. Granting the land as a gift of the ancestors' victory seems to revalidate that the land belongs to them.

Citing from the land owner from Mongkos village;

"...Before the Japanese time this village already existed...1940 or $1939 . . . "$

Asked from where do they get the information about the opening of the village, majority explained that their grandfathers told them. This matter is related to their needs fpr the land. Majority of the landowners agreed that land is important in the Bidayuh community as a symbol of their identity. This situation is important to create their continuity from one generation to another.

Therefore, gathering the historical factors, such as when was the land occupied and so forth need to be used as an evidence to strenghten the inputs relating to the validity of their ownership of the land all these while.

\subsection{Determination of boundaries through physical signs marking the original formation of the boundry}

To the Bidayuh community, the land determination of ownership and delimitation are determined by the community through the use of natural resources such as trees, rivers and so on. Among those commonly found in the study area as the boundry "line" is the bamboo tree. Area boundary marking using the tree boundry, will not only known to the community in their group but also known by another group from other tribes. Thus, that is the role of the head of custom or the tuai rumah and the community leader like Temenggung. This matter is very important to recognize the rights of ownership of the land explored in particular the customary land owned since the Japanese occupation (Azima et al 2014).

Results of the interviews with the landowners in the study area found that they determined the boundaries of their land by using common rules understood by the local community using the physical marking, such as bamboo. The general rule in regards to the boundaries and ownership of the land were understood by them through the oral information inherited from one generation to another. When asked to one of the customary landowner, he acknowledged that the land boundary was made by their ancestors who eventually past down to the grandchildren. Asked about the marking method, citing from the land owner $Y$ from the Mentu village, he explains;

"... Yes it was done by the older generation, we just follow..."

This matter explains that the General rules on boundries determined by the elderly were eventually past down to the children. Thus, it is important for them to understand the physical signs that were used by their ancestors to really show their land boundaries. Citing from the land owner $\mathrm{G}$ from the Mongkos village who further explained that the boundries were determined by the ancestors:

"... Last time my grandfather. Like planting the bamboo... so that he can see..."

Through this general rule their rights towards the land explored is inherited as well as guaranteed by the community. Later, it was marked with a natural border known as 'lines' such as rivers, trees, crest and other permanent landmarks (Azima et.al 2014). The use of bamboo trees was very synonymous in laying the boundry for the land that has been explored. Observations in the field explained that bamboo trees have been made as a symbol to mark the land boundaries that turned out to be understood by the local community.

Citing the words of one of the land owner in Mongkos village, he explained that;

"...Bamboo. Yes indeed is for our border., an advantage we use bamboo because if it is planted must live and hard to die. Second we use streams or the hill. But we must want to grow bamboo, must grow... " 
In addition, landowner J from the Mentu Tupu village also explained that;

"...ohh if we are here in the ancient time we used bamboo, this border between the two of us...straight like this... we planted here a straight bamboolah...not crooked...straight like this...if crooked, at the end will also fight. That's why last time our ancestors sometimes they planted bamboo, the rubber use boundry..."

In addition to the use of bamboo, residents in the study area also mark their boundaries by using streams, rubber trees, diamond wood and hills. This is clear through the landowner A from Kampung Mongkos and landowner $\mathrm{H}$ from the Mentu Tumpu village that explained;

"It was our way last time used bamboo and rubber..."

"...that is the mark...use wood..."

In addition, there is also evidence that the villagers were using streams to mark their land boundaries. Land owner $\mathrm{J}$ from Mongkos village explained that;

"...the second boundry he used the stream. He doesn't bother whether the stream is crooked or not, he will follow the stream..."

In summary, findings with the land owners in the study area found that the land boundaries were determined by members of it's community using an informal information obtained by hereditary. This situation creates insecurity in the context of land ownership. This is in accordance with the findings highlighted by Verplanke and McCall (2014), Keresi et al (2014), Rakai et al (1995) Paaga (2013) and Cotula (2006) following their study in several countries such as Fiji, the Philippines, Ghana, Tanzania and Nigeria. Insecurity here means fear of losing the rights on the land occupied since the time of their ancestors. This matter is obvious because according to the customary terms, it is found that their rights to the land were driven by the trust of the community towards the Chief appointed to represent the custom. Chiefs in the native communities are strongly trusted and they will keep all information relating to the members under their guardianship. In this regard, in the Bidayuh community, the tuai rumah and the head of Bidayuh custom become very important in maintaining the trust of their tribe. In the event of defection by the chief, certainly a wealth of information about their rights to the land will be denied. This situation will create a number of disputes in connection with the inaccurate information and sometimes misused. This matter is clear where there are complaints from a few landowners in Kampung Mongkos that is;

"... Only we are concerned ... people who are dishonest, I mean the chief... "

Hence, insecurity among the land owners with the tribal chief, siblings can also lead to the dispute relating to the land ownership.

"... our own problem is that ... people who betray ... people who cheat ... that's what we are worried ... who use abusive words every time ... later there will be a defactor..."

Observation in the study area found that the dispute on land ownership includes three aspects, that is, the dispute among family members, dispute with the private sector/investors and dispute with the State Government in the land ownership matter.

\subsection{Dispute among the family members}

The communities' insecurity on their rights towards the land clarifies that there has been disputes among their own family members. Dispute regarding rights to the land occurred among siblings and with the neighbours next to their land boundaries. Disputes among family members are related to the land which still does not have titles. This matter is evident through the grievances of some of the respondents met who acknowledged that;

$$
\text { "...the land scramble is not among others, but our own families because the existing land still has no title..." }
$$

Disputes among owners of the adjacent boundaries were related to the confusion of the land owners in relation to the already existing boundaries. For example reponden $\mathrm{D}$ explained that; 
'... Because the boundry that use bamboo sometimes the bamboo enter. Enter in little-bit. Because it is common that the bamboo if we plant here, it will grow elsewhere. That there is a little fight ...'

This situation encourages landowners to expedite the efforts to measure their land

However, the disputes within the family or the neighboring land owner can be managed easily through discussions with the village headmen. It is evident;

"...discuss with the village headman, the headman will settle la..."

However, the dispute of the land owners with the village head as a source of information gathering on the customary land belonging to the tribe has started to be disputed by many land owners. They suspected that the village head was also involved in the sale of the customary land to outsiders. Citing a complaint from landowner $F$ in Mongkos village;

"... it was the headmen who cheated the villagers ... just like in the up steam orchard ... somebody's land was sold ..."

This situation explains the existence of insecurity among the land owners when the feelings of suspicion and distrust upon the leaders that stores information on their customary land in the context of the unwritten information in the form of owners title and so forth. The situations eventually call for the dispute among landowners.

\subsection{Disputes of the customary land owners of private companies}

The fear of their rights on the land are being encroached by the outside companies cause them to really want a clear land ownership among others by having recognized land titles. The customary land owners in the area of study explained that every day their land are being encroached by private parties who carry out the planting of oil palm on customary land that belongs to their families. Complaints from the land owners clarified that;

"look at that land belong to the local... the palm oil belongs to the company... this is the big land, they confiscate, they plantt palm oil la..."

Encroachment by the large companies for the purpose of oil palm planting was seen as among the biggest threat to the customary land in the area of study. Every day they fear that their land will be encroached and planted with oil palm.

"...not only my family... the whole village they have taken... the land area they have taken from the jungle up to there..."

This situation explains the existence of encroachment by private parties for the purpose of oil palm planting. Fear of their customary land being encroached cause them to require the individual land ownership titles. Furthermore, if their land were encroached, the effort to regain the land will take a long time and involve a lot of cost. This is evident when among them who mentioned;

"...but until now it is not settle, not only me... that case also don't know when will settle... still no payment..."

"...until now the palm oil has grown tall and has been eaten.." but my case, child is a few years already... maybe more than 10 years until now not finish yet..."

The land owners dispute with the private companies normally will take a long time to be settled. The absence of defence from the agency caused them to be haunted by great worries.

They explained that the defence of the land encroached by the companies is assisted by NGOs such as BRIMASS. It is evident when they stated;

"..its like NGO la...they have lawyer..."

"There are arguments but like going to the court, but the company has a lot of money that they can pay big lawyer ... later lost can't even get a cent..."

Fear of losing the rights coupled with the inability to make claims cause the land dispute to prolong on the landowners' side. To the extent that there are some of them who are willing to take individual action if the issue prolonged, among others; 
"...if my action it is easy...if like me lah give me back the land..."

"... just scolded the company...I said cannot disturb, not even an inch... I am bad I said whoever tresspassed I will kill. I am not afraid, that is our siblings rights..."

\subsection{Dispute with the state government}

Mulenga (2005) explains that the land is the primary source for the community to continue their living. Therefore, it is not surprising that Muchima (2006) explains that most of the existing land allocation are intended to protect the rights of the land owners. In Sarawak, it is evident that the existing land allocation not only were intended to protect but also to recognize the validity of the customary land ownership by the owner.

However, the dispute between the landowners and the state government cannot be denied. Often the locals described that the land encroachment issue is associated with the approval given by the state government. It was evident when there were among land owners who complaint that;

"...yaa... but after government can give to us because it is the people who took care of the land... that is why we are not stisfied..."

"... last time there was land but like it was taken force by the private... do not know if taken by company through who..."

"...many orchards here that were taken that is the rainforest land but we appeal to the government..."

Disputes involving acquisitions and changes of the land status to stateland is an issue that is often raised by them. They are very worried that suddenly their land will be acquired for the development purposes. To the land owners, they consider that the NCR land law cannot protect their rights to the land they own. This matter is evident when;

"...true, the NCR law will not protect hundred percent it is said in Sarawak only in the name of NCR. Who is helping is not known. The NCR land will be transfered to the stateland. The native die..."

Other than that, the dispute related to the state government is regarding the compensation payment issue which is not commensurate, this is among matters that has become the main complaint of the resident. Once their land was taken for the development purposes or given to the private sector for the commercial oil palm planting, it was found that the land owners were never paid. Citing complaints from some of the landowners who explained that;

"...yaa unpaid...the new one was also taken with force. You don't take the money I will take the land by force... I have to take the money, if I don't take the money...free..."

However, there were among these people who were paid compensation, but it was insufficient.This matter is evident true the grievances from the land owners whose land had been acquired by the state government;

"...there are compensation given...but it is not sufficient lah..."

"...like my case, my aunty's parents were affected too..until now not paid..."

\subsection{Implication from the land delimitation dispute}

Customary land ownership dispute in the study area has to do with their approach in determining the land boundaries. Much of the information on the land were obtained through the primary information obtained from their ancestors. The boundry demarcation among which were using natural resources such as trees, hills, and others will eventually be rejected by the development. Majority of the villagers are clear about the boundaries of their land but what becomes the question is related to the ownership of the land. Hence, it is important for everyone to make sure that their land were measured, and if the it has been measured, then they will have a valid right to the land. By having the clear ownership title, ongoing dispute between themselves, dispute with the company and also the dispute with the state government will be avoidable. This is evident through grievances from the land owner;

"...land measuring is most needed ...if not it will be difficult...every year there will be conflict..."

"...if people has already measured...there need to have a title..."

In this matter, the land title or grant became important to the villagers. With the title they can provide proof of ownership validity on the land. Therefore, it is not surprising if everyone involved in the study area had agreed and are attempting to carry out their village land measuring work and subsequently received the titles. This is evident when the 
villagers had requested DBNA to measure their land under the provision provided by the government. To expediate the land measuring work, the residents of the land involved had hired outside or the private land surveyor to measure their land. And among them there were those who had paid the land surveying cost conducted by the outside surveyor. This is done to expediate the title application period for their village land.

In addition, the impact of market expansion has also become a major challenge to the landowners to maintain the land bequeathed to them. Their fear of land encroachment and aquisation had cause them to take action to obtain the land title. Besides, the issue of compensation which is rather vague and not siding the customary land owners will be solved if they have the valid rights to the land. This matter is evident when among the landowners who mentioned that;

"...because we don't have balck and white, they have money, they just reject la... we don't have black and white how to fight..."

This citation clarifies that their power became very limited in the customary land context. The ability to make claim in court will normally take a long time. This will definitely put more pressure when most evidences of their ownership on the land are purely oral among the community chiefs and heads of the households. The proof of ownership need to be proven that they have occupied the customary land even before the Japanese occupation.

\section{Conclusion}

In conclusion, this study has shown that the dispute in regards to the customary land ownership in the study area is related to the approach in determining the boundaries by the landowners. The delimitation differences used by the relevant agencies had caused the dispute in the land ownership context in the study area. Eventually, the situation has created uneasiness, suspicion and will further become a great challenge to the development of the study area. The implication from the differences in the boundry visualization has created insecurity among the land owners and eventually enable them to consider the need to obtain the valid land titles. In this regard the agencies involved should provide space for indigenous peoples to clarify the meaning of land and real estate they desire. Understanding of the meaning and requirements of the agency ancestral land of the indigenous peoples will allow some agreement that is a win - win situation raised by both parties. Therefore, before any proposal is made in the development of customary land, should be proposed in order to make a social index that takes into account land tenure and socio-cultural aspects of power.

\section{Acknowledgement}

This study was funded by the Ministry of Higher Education under the External Grant Code FRGS/1/2013/SS06/UKM/03/1.

\section{References}

Azima A. M, Novel Lyndon, Sivapalan Selvadurai, Mohd Yusof Hussain, Zaimah Ramli, Sarmila Md Sum, Suhana Saad, Mokhtar Jaafar dan Fuad Mat Jali. (2014). Cabaran tranformasi Tanah NCR: satu keperluan terhadap metod Pemetaan Berpenglibatan. Jurnal Geografia Vol 10 (1) : 110-117

Azima A.M, Novel Lyndon, Zaimah Ramli,Suhana Saad, Sarmila Md Sum, Yusoff Hussain, Abdul Hair Awang, Sivapalan Selvadurai, Fuad Mat Jali dan Mokhtar Jaafar. (2014). Memahami makna persempadanan dan pemilikan tanah NCR oleh komuniti Bidayuh di Sarawak. Prosiding Persidangan Kebangsaan Ekonomi Malaysia KE-9 17- 19 Sept 2014 Kuala Terengganu, Terengganu

Adam, M. (2003) Land tenure policy and practise in Zambia:issues relating to the development of the Agriculture Sector. CASLE Conference Paper. 2003.

Borneo Resources Institute Malaysia (BRIMAS). (1999). Buku Kecil Tanah Adat Bumiputra dan Undang-Undang di Sarawak. Kuching: Sarawak

Contula L. (2006). Key concept and trends in policy and legislation. International Institute for Environment dan Development. Issue 139 pg 9-20

Fleischacker S.I.. (1994). The ethnics of culture. Itaca: Cornell University Press.

Hallman T. (1994). Land Boundaries. Intergoverment Committee on Sureying and Mapping.

Survey Review 10 (6): 80 -102

Mulenga, J. (2005). Foreword on communities views on land policy in Zambia. Survey Review 21 (6): 90 -102

Muchima. (2006). Land tenure and boundary conflicts in rural Zambia. CASLE Conference Paper 2006.

Keresi R. Lisa Ting and lan P. (2014). Dispute Resolution for Customar lands: some lesson from Fiji. Survey Review 26 (12): $355-366$

Kasanga and Kotey. (2001). Land management in Ghana:Building on tradition and modernity. Survey Review 20 (12): 300 -312

Kirby, J.P. (2005). The earth cult and ecology of peace building in Northern Ghana. In D, Miller, S.B. Kendie, A. A. And B. Haverkort (eds), African knowledges and sciences:understanding and supporting the ways of knowing in sub-Saharan Africa. The 
Netherland:Barneveld

Paaga D. T. (2013). Customary land tenure and its impilacations for land disputes in Ghana: cases from Wa, Wechu and Lambussie. International Journal of Humanities and Sosial Science. Vol 3 No 18 pg 263-270

Rakai, M and Williamson. (1995). Impelementing LIS/GIS from customary land tenure perspective - teh Fiji experience. The Australia Surveyor. 40 (2) 112-121

Rob C., and Patrick S. (2011). Shifting ground: renegotiating land rights and rural livelihoods in Sarawak, Malaysia. Journal Asia Pacific Viewpoint. Vol 52 (2) 136-147

Stephan Rist,Mani Chidambararnathan,Cesar Escobar,Anne Zimmermann.(2007). Moving from sustainable management to sustainable governancee of natural resources:The role of social learning processes in rural India,Bolivia and Mali. Journal of Rural Studies 23 (1) $23-37$

Suruhanjaya Hak Asasi Manusia (SUHAKAM). (2013). Laporan Inkuiri Naional Mengenai Hak Tanah Orang Asal/Asli. Terbitan Suruhajaya Hak Asasi Manusia: Kuala Lumpur

Sabah, Sarawak CJ:Time to set up native land tribunal. Borneo Post. 31 January 2012

Kanun Tanah Sarawak pindaan 1994

Verplanke,J.J. dan Mc Call M.K. (2014). Boundary dispute settlement using mobile GIS. The Australia Surveyor, 30 (1):112-121.

Wehrmann B. (2008). Land conflicts:a practical guide to dealing with land disputes. Eschborn German: Deutsche Gesellscharf. 